Patofisiologi merupakan disiplin ilmu yang mempelajari tentang perjalanan penyakit serta perubahan yang ditimbulkannya, baik itu tentang mekanisme dan proses dinamik yang menampakkan tanda dan gejala penyakit.

Buku ini memberikan pemahaman kepada mahasiswa keperawatan tentang patofisiologi dasar seperti mekanisme adaptasi sel (proses cedera fisik, penyembuhan dan kematian sel), kelainan interaksi genetika, keseimbangan cairan, elektronik dan asam basa, proses imunitas, degeneratif dan proses terjadinya shock.

Buku ini merupakan hasil kolaborasi dosen Universitas Muhammadiyah Kalimantan Timur dan Sekolah Tinggi IImu Kesehatan (STIKES) Dirgahayu Samarinda. Kedua penulis berpengalaman dalam mengajarkan mata kuliah patofisiologi pada Program Studi Keperawatan.

Buku ini sangat diperlukan bagi mahasiswa keperawatan yang akan memberikan asuhan keperawatan kepada pasien. Sebab dengan menggunakan dasar ilmu patofisiologi maka asuhan keperawatan mulai dari pengkajian sampai dengan evaluasi yang diberikan pada pasien menjadi rasional sehingga berhasil optimal.

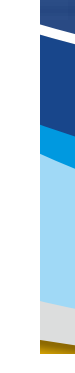

Ns. Annaas Budi Setyawan, S. Kep, M.Si.Med Ns. Yani, S.Kep, M.Pd.

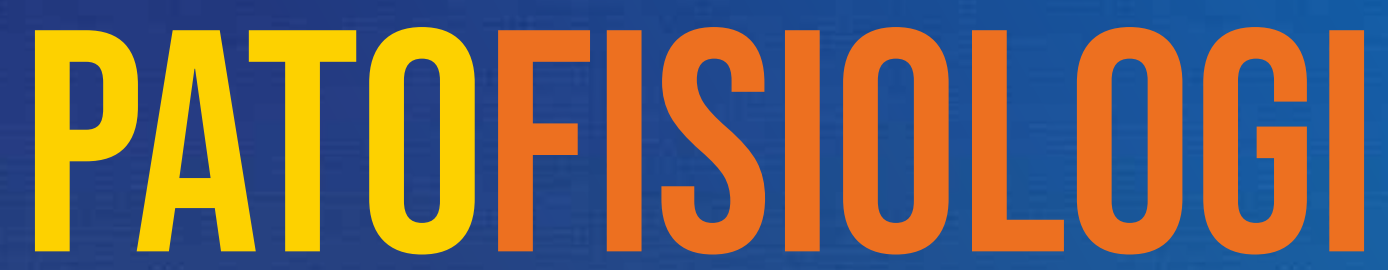
UNTUK MAHASSSWA KEPERAWATAN
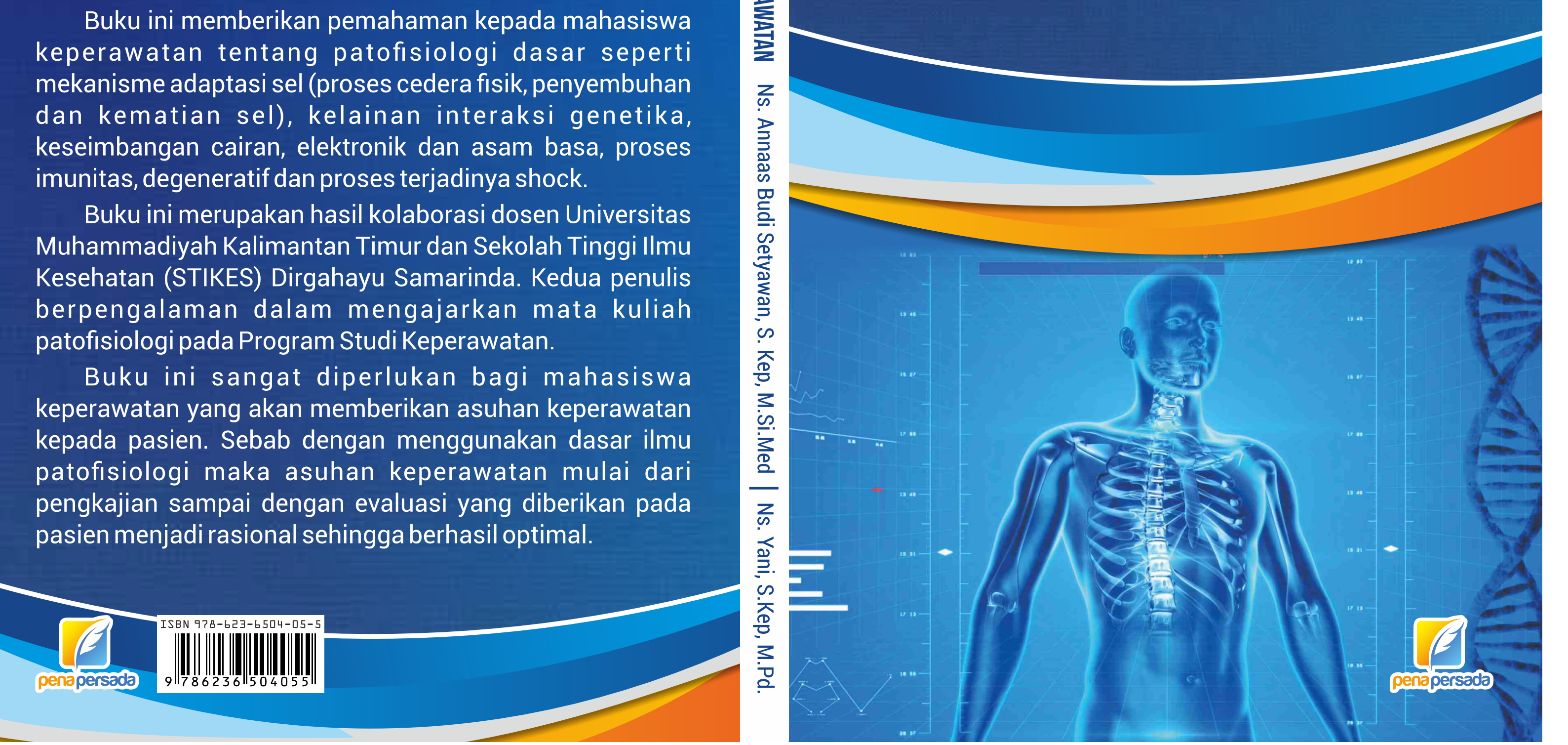


\title{
PATOFISIOLOGI UNTUK MAHASISWA KEPERAWATAN
}

\author{
Annas Budi Setyawan \\ Yan i
}

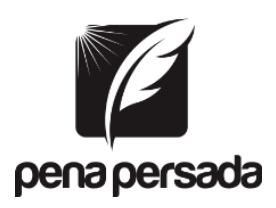

PENERBIT CV. PENA PERSADA 


\section{PATOFISIOLOGI UNTUK \\ MAHASISWAKEPERAWATAN}

Penulis:

Annaas Budi Setyawan

Yani

ISBN : 978-623- 6504-05-5

Desain Sampul :

Retnani Nur Briliant

Penata Letak :

Fajar T. Septiono

Penerbit CV. Pena Persada

Redaksi :

Jl. Gerilya No. 292 Purwokerto Selatan, Kab. Banyumas

Jawa Tengah

Email : penerbit.penapersada@gmail.com

Website : penapersada.com

Phone : (0281) 7771388

\section{Anggota IKAPI}

All right reserved

Cetakan pertama : 2020

Hak Cipta dilindungi oleh undang-undang.

Dilarang memperbanyak karya tulis ini dalam bentuk dan cara apapun tanpa izin penerbit. 


\section{DAFTAR ISI}

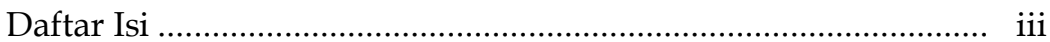

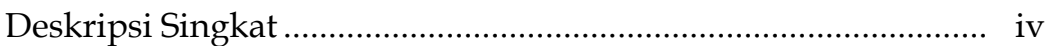

Relevansi............................................................................. iv

Tujuan Instruksional.................................................................... $\mathrm{v}$

Petunjuk Belajar ...................................................................... v

\section{BAB I}

MEKANISME ADAPTASI SEL …..................................... 1

PENDAHULUAN .................................................................. 1

TUJUAN …

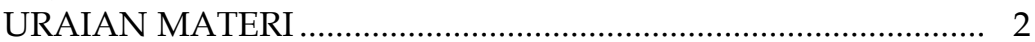

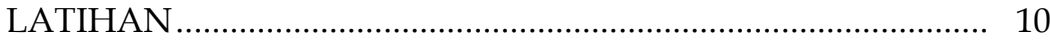

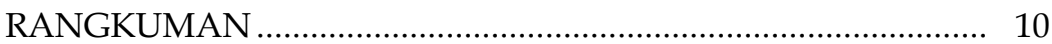

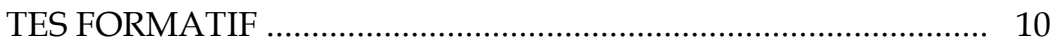

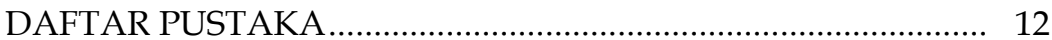

\section{BAB II}

KELAINAN DAN INTERAKASI GENETIKA ........................... 13

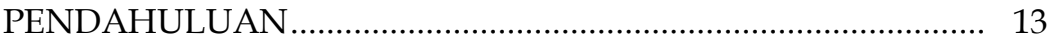

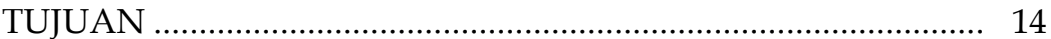

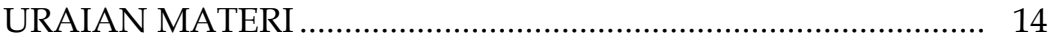

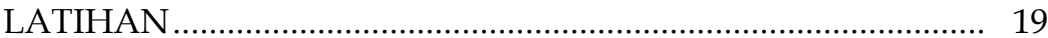

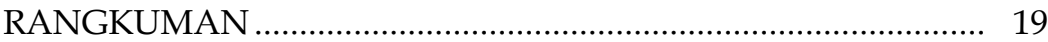

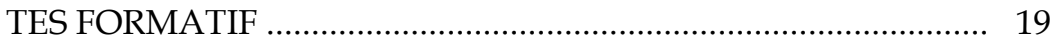

\section{BAB III}

KESEIMBANGAN CAIRAN, ELEKTRONIK DAN ASAM

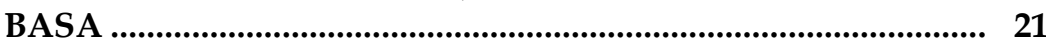

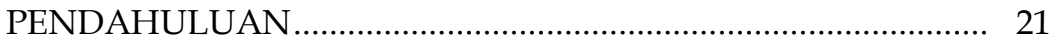

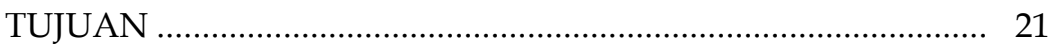

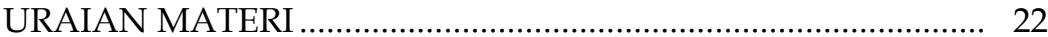

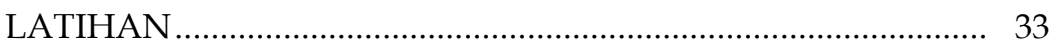

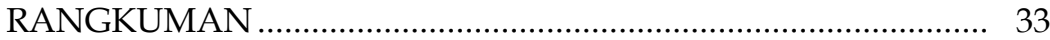

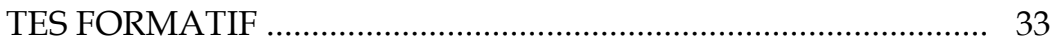

\section{BAB IV}

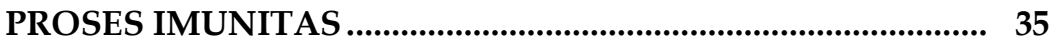

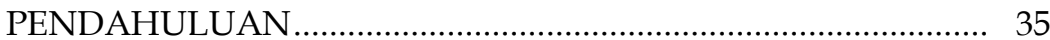

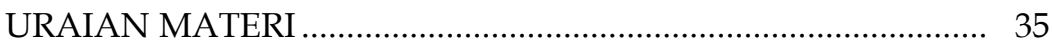

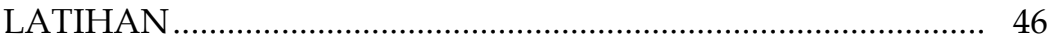




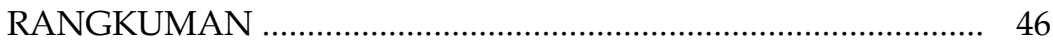

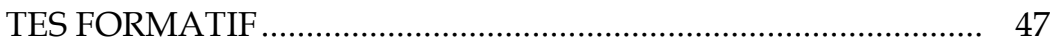

BAB V

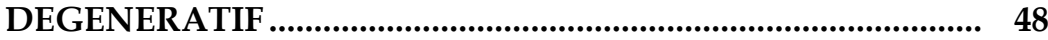

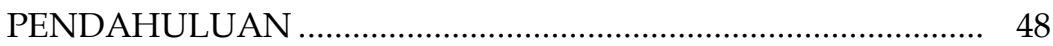

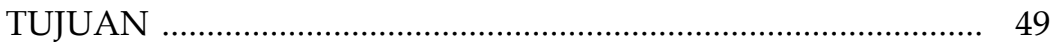

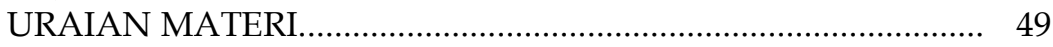

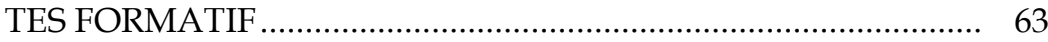

BAB VI

PROSES TERJADINYA SHOCK ................................................... 64

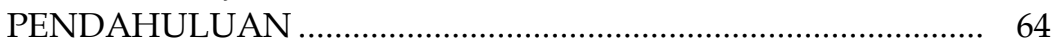

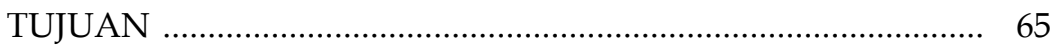

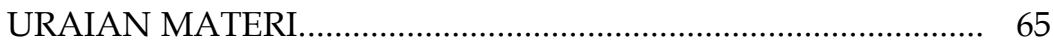

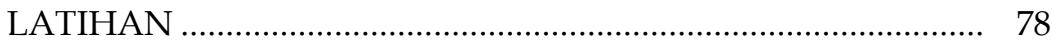

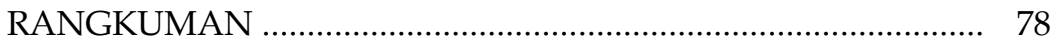

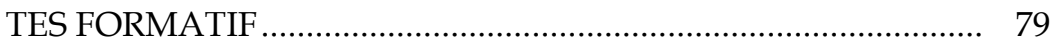

Daftar Pustaka ................................. 81 


\section{PENDAHULUAN}

Deskripsi Singkat, Relevansi, Tujuan, dan Petujuk Belajar

\section{DESKRIPSI SINGKAT}

Mata kuliah ini membahas tentang mekanisme adaptasi sel (Proses cidera fisik, penyembuhan dan pemulihan dan kematian jaringan/nekrosis sel meliputi: atropi, hipertropi, iskemik, thrombosis, embolism), kelainan dan interaksi genetik, proses keganasan, tahapan perkembangan mental dan perubahan kesehatan (perkembangan reproduksi, perkembangan anak, dewasa, orang tua/lansia), proses perubahan keseimbangan cairan, elektronik dan asam basa, antara lain : proses odem, hiper dan hipo elektrolit, asidosis dan alkalosis), proses infeksi, proses peradangan, proses imunitas, proses degenerative, proses terjadinya shock.

\section{RELEVANSI}

Modul dalam buku ini sangat diperlukan bagi mahasiswa keperawatan yang akan memberikan asuhan keperawatan kepada pasien. Sebab dengan menggunakan dasar ilmu patofisiologi maka asuhan keperawatan mulai dari rencana tindakan keperawatan sampai dengan mengevaluasi tindakan keperawatan yang diberikan pada pasien menjadi rasional sehingga berhasil optimal.

Dengan pemahaman yang baik pada mata kuliah ini maka dalam kegiatan belajar akan mampu mengenal dan memahami konsep penyakit dan juga akan memperoleh pengetahuan tentang kelainan yang sering terjadi pada pasien akibat penyakit yang diderita. 


\section{TUJUAN INSTRUKSIOAL}

Setelah mengikuti mata kuliah patofisiologi mahasiswa semester II akan dapat menerapkan konsep patologi dan patofisiologi kelainan struktur dan fungsi tubuh.

\section{PETUJUK BELAJAR}

1. Pahami berbagai istilah dalam ilmu patofisiologi yang digunakan dalam modul ini

2. Keberhasilan tergantung pada kesungghan belajar, oleh karena itu kerjakan latihan dan tugas secara mandiri

3. Ketika menemukan kesulitan segera hubungi dosen yang mengajar mata kuliah patofisiologi 
KEG IATAN BELAJAR: 1

MEKANISME ADAPTASISEL

\section{PENDAHULUAN}

Penyakit apapun yang diderita oleh pasien pada dasarnya yang diserang adalah sel dan sel akan melakukan adapatasi (menyesuaikan diri). Sel normal merupakan mikrokosmos yang berdenyut tanpa henti, secara tetap mengubah stuktur dan fungsinya untuk memberi reaksi terhadap tantangan dan tekanan yang selalu berubah. Bila tekanan atau rangsangan terlalu berat, struktur dan fungsi sel cenderung bertahan dalam jangkauan yang relatif sempit.

Tubuh kita terdiri dari satuan dasar yang hidup yakni berupa sel-sel. Kemudian sel-sel tersebut akan berkelompok membentuk jaringan yang berbeda-beda yang saling menghubungkan satu sama lainnya. Setiap sel dapat beradaptasi dan berkemampuan untuk berkembang biak. Bila sel tersebut rusak dan mati, maka sel-sel yang masih hidup akan terus membelah diri terus menerus sampai jumlahnya mencukupi kembali.

Penyesuaian sel mencapai perubahan yang menetap, mempertahankan kesehatan sel meskipun tekanan berlanjut. Tetapi bila batas kemampuan adaptasi tersebut melampaui batas maka akan terjadi jejas sel atau cidera sel bahkan kematian sel. Dalam bereaksi terhadap tekanan yang berat maka sel akan menyesuaikan diri, kemudian terjadi jejas sel atau cidera sel yang akan dapat pulih kembali dan jika tidak dapat pulih kembali sel tersebut akan mengalami kematian sel.

\section{TUJUAN}

Mahasiswa mampu menguasai konsep tentang mekanisme adaptasi sel 


\section{URAIAN MATERI}

A. Struktur Sel

Sel mengandung struktur fisik yang terorganisir dinamakan organel yang terdiri dari dua bagian utama yaitu inti (Nucleus) dan Sitoplasma (Cytoplasma) keduanya dipisahkan oleh membrane inti. Berikut disajikan dalam gambar sel dan bagian-bagiannya:

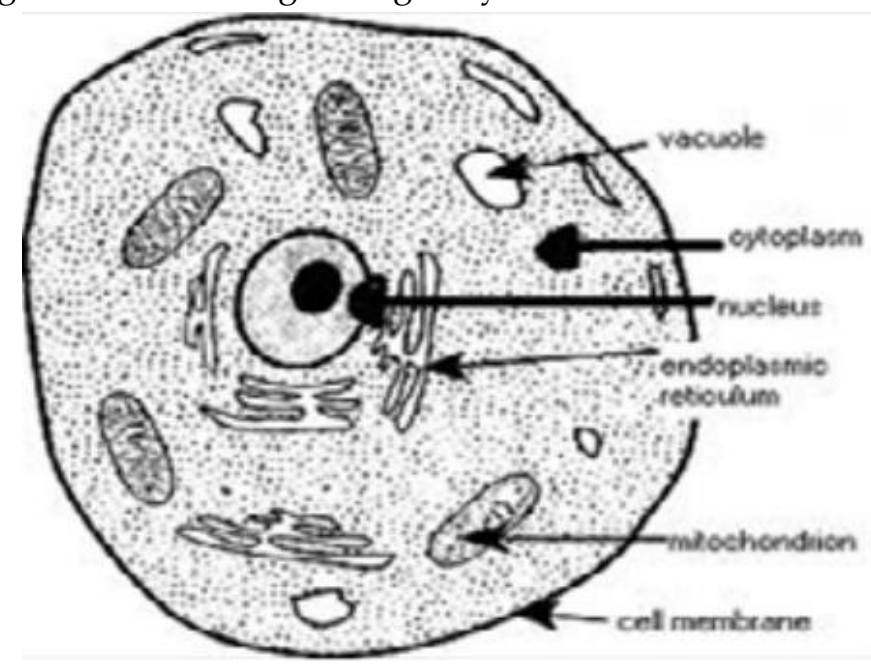

Gb.1: Bagian sel

Beberapa bagian sel penting dan fungsinya yang harus diketahui:

1. Retikulum endoplasma (Endoplasmic Reticulum) berfungsi dalam mensintesis protein, lipid dan enzim.

2. Mitokondria (mitochondrion) berfungsi untuk energi dalam sel. Merupakan sumber tenaga dari sel karena diolah berbagai zat makanan untuk menghasilkan tenaga penggerak bagi kegiatan lain dari sel.

3. Lisosom merupakan organ pencernaan sel

4. Inti (nucleus) berfungsi sebagai pusat pengawasan atau pengaturan sel dan mengandung DNA yang disebut gen.

B. Cidera Sel (Jejas sel)

Tubuh seorang manusia mudah mendapat berbagai macam cidera setiap saat, ini beraarti cidera tersebut dialami 
oleh sel. Jejas sel (cidera sel) terjadi apabila suatu sel tidak lagi dapat beradaptasi terhadap rangsangan. Hal ini dapat terjadi bila rangsangan tersebut terlalu lama atau terlalu berat. Sel dapat pulih dari cidera atau mati bergantung pada sel tersebut dan besar serta jenis cidera Berikut ini berbagai penyebab cidera sel (Price, 2007) :

1. Hipoksia

Hipoksia adalah cidera sel akibat penurunan konsentrasi oksigen. Hipoksia bisa terjadi karena hilangnya perbekalan darah akibat gangguan aliran darah. Dapat juga karena hilangnya kemampuan darah mengangkut oksigen seperti karena anemia atau keracunan. Respon adaptasi sel terhadap hipoksia tergantung pada tingkat keparahan hipoksia.

2. Bahan kimia

Bahan kimia termasuk obat-obatan menyebabkan perubahan terhadap berbagai fungsi sel, seperti fungsi penghasil energy, mencerna lipid dan protein sehingga sel menjadi rusak dan mati. Sebagai contoh ulkus lambung (luka pada lambung) yang sering terjadi karena sering mengkonsumsi obat analgetik dan kortikosteroid. Hal tersebut menyebabkan sel mukosa lambung cidera dan rusak dan akhirnya terjadi ulkus (luka).

3. Agen fisik

Agen fisik seperti trauma mekanik, suhu rendah dan suhu terlalu tinggi, radiasi dan trauma listrik. Semua agen fisik tersebut dapat menyebabkan perubahan atau pergeseran struktur sel yang mengakibatkan terganggunya fungsi sel yang akhirnya menyebabkan kematian sel 

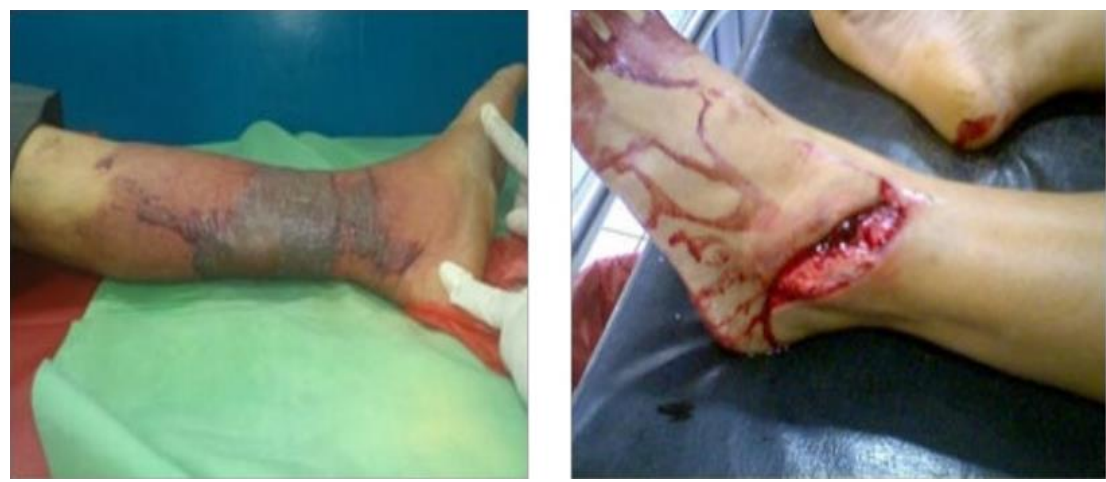

Gb.2: Bagian tubuh yang rusak akibat agen fisik

4. Agen mikrobiologi

Agen mikrobiologi adalah berbagai jenis bakteri, virus, mikoplasma, klamida, jamur dan protozoa yang mengeluarkan eksotoksin yang dapat merusak dinding sel sehingga dinding fungsi sel terganggu dan akhirnya menyebabkan kematian sel.

\section{Mekanisem imun}

Reaksi imun sering menjadi penyebab kerusakan pada sel. Sebagai contoh penyakit alergi yang sering dialami pasien usia lanjut atau karena reaksi imun lain yang menimbulkan gatal atau kerusakan sel kulit.

C. Mekanisme Adaptasi Sel

Agar sel terus menjalankan fungsinya maka sel harus melakukan mekanisme adaptasi saat mendapatkan cidera sehingga sel dapat bertahan hidup. Ditinjau dari beban kerja sel, maka adaptasi sel dapat dibagi menjadi:

1. Adaptasi terhadap peningkatan beban kerja sel

2. Adaptasi terhadap penurunan beban kerja sel

Berikut ini adalah bentuk adaptasi yang dilakukan sel (Nair, 2015) : 
1. Menambah ukuran sel (hipertrofi)

Didefinisikan sebagai pembesaran jaringan atau organ karena pembesaran selnya yang tidak disertai peningkatan fungsi organ atau jaringan tersebut. Hipertrofi dapat bersifat fisiologik dan patologik. Sebagai contoh kondisi hipertrofi patologik dapat dilihat pada jaringan otot jantung yang mengalami peningkatan beban kerja seperti pada pasien yang bertahun-tahun menderita hipertensi. Sedangkan kondisi hipertrofi fisiologik seperti otot rangka pada binaragawan yang memang sengaja dibentuk sebagai hasil mengangkat beban berat.

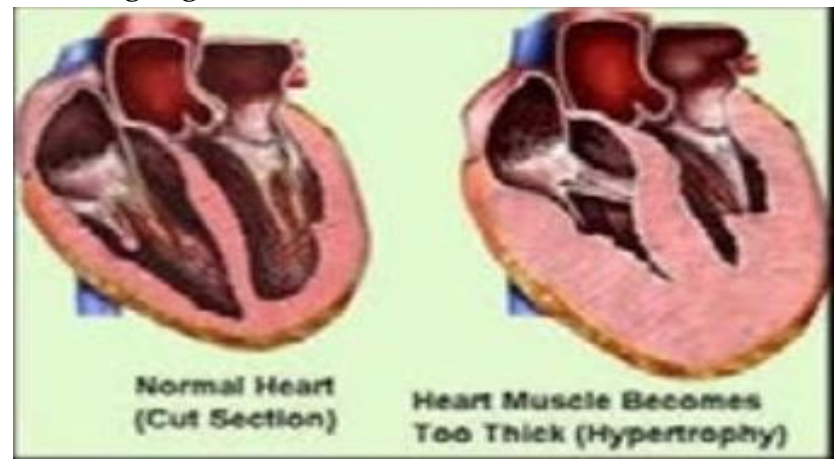

Gb.3: Hipertrofi patologik pada otot jantung

2. Mengurangi ukuran sel (Atropi)

Kejadian dimana organ atau jaringan yang terbentuk tumbuh mencapai batas normal tetap kemudian mengalami penyusutas. Sifatnya dapat fisiologik misalnya pada proses aging (penuaan) dimana seluruh bagian tubuh tampak mengecil bertahap. Lebih jelas jikadilihat pada usia lanjut yang mengalami atrofi endokrin sehingga produk hormonnya menurun. Atropi patologik dapat terjadi pada otot individu yang mengalami immobilisasi sehingga otot tidak pernah digerakkan sehingga otot akan semakin mengecil. 


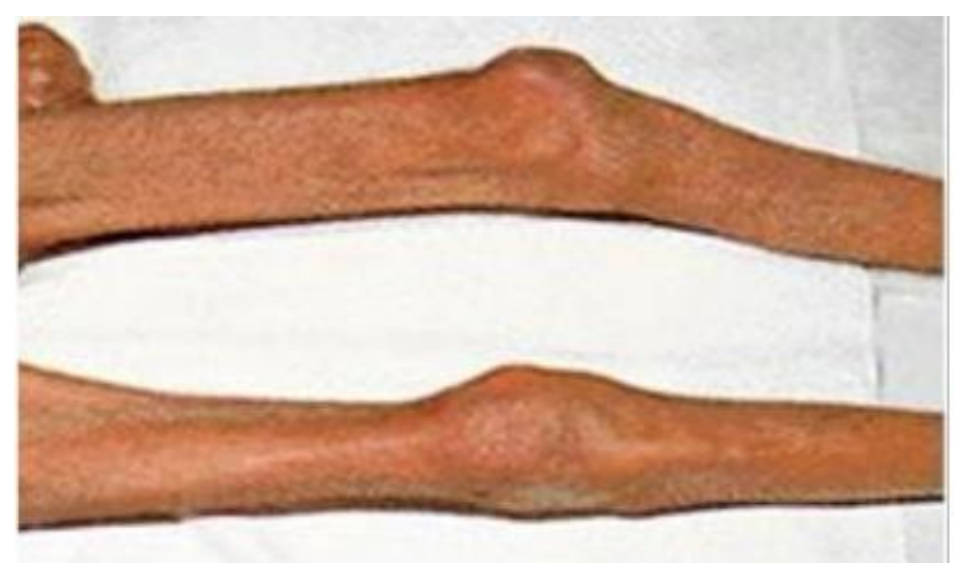

Gb.4: Atrofi otot kaki

3. Menambah jumlah sel (hyperplasia)

Hiperplasia terjadi karrena kenaikan absolute pada sebuah jaringan atau organ sehingga menyebabkan pembesaran jaringan atau organ tersebut dan fungsi organ atau jaringan tersebut juga meningkat. Hal ini hanya dapat terjadi pada sel labil seperti sel epidermis atau sel darah. Tidak terjadi pada sel permanent seperti sel otot rangka, saraf dan jantung. Contoh hiperplasi fisiologik adalah pembesaran sel uterus pada saat seorang wanita hamil sehingga janin dapat tumbuh membesar didalamnya. Sedangkan hiperplasi patologik biasanya terjadi karena rangsangan hormonal berlebih misalnya hyperplasia endometrium akibat pengeluaran hormon estrogen yang tidak terkendali dan merupakan prekursor terjadinya proliferasi keganasan. 


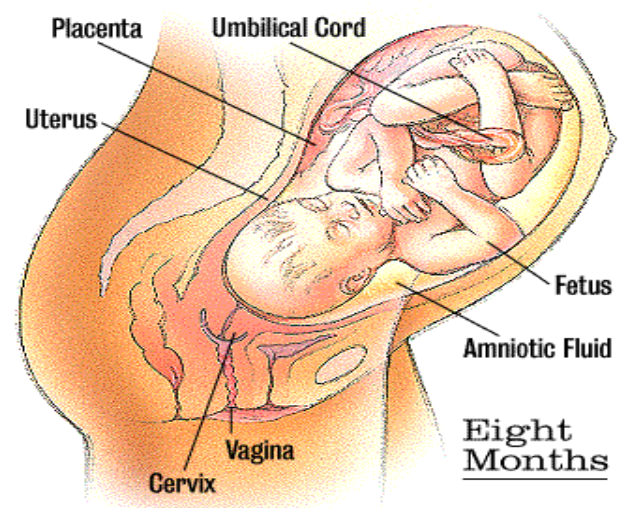

Gb.5: Hiperplasia fisiologik, pembesaran uterus sesuai janin

4. Merubah sel (metaplasia)

Bentuk adaptasi yang terjadi berupa perubahan sel matur jenis tertentu menjadi sel matur jenis lain. Misalnya sel epitel torak yang dapat bersekresi diganti oleh sel epitel gepeng berlapis yang tidak dapat bersekresi yang terjadi pada saluran pernafasan seorang perokok. Hal ini tidak menguntungkan karena lender yang merupakan alat proteksi saluran pernafasan terhadap bakteri debu dan benda asing tidak terbentuk sehingga saluran pernafasan mudah mengalami infeksi.

D. Kematian Sel

Sebelumnya sudah dibahas bahwa cidera dan kematian sel dapat disebabkan kekurangan oksigen (hipoksia), bahan kimia, agen fisik, agen mikrobiologi dan mekanisme imun. Berdasarkan tingkat kerusakannya, cedera atau jejas sel dikelompokkan menjadi 2 kategori utama yaitu jejas reversible (degenerasi sel) dan jejas irreversible (kematian sel). Jejas reversible adalah suatu keadaan ketika sel dapat kembali ke fungsi dan morfologi semula jika rangsangan perusak ditiadakan. Sedangkan jejas irreversible adalah suatu keadaan saat kerusakan berlangsung secara terus-menerus, sehingga sel tidak dapat kembali ke keadaan semula dan sel itu akan mati. 
Kekurangan oksigen (hipoksia) adalah penyebab paling umum cedera dan kematian selular. Kondisi berikut dapat menimbulkan masalah seperti iskemia, trombosis, emboli, infark dan nekrosis (Tambayong, 2016). Cedera ini bersifat reversible pada beberapa keadaan, atau dapat berlanjut menjadi permanen (ireversibel).

1. Iskemik

Iskemik merupakan kekurangan suplai darah pada area terlokalisasi. Keadaan ini bersifat reversible, yaitu jaringan kembali pada fungsi normal setelah oksigen dialirkan kembali. Iskemik biasanya terjadi pada adanya aterosklerosis, yaitu penyempitan pada pembuluh darah akibat penimbunan lipid atau lemak. Contoh keadaan ini adalah angina pektoris pada jantung yang memiliki gejala klinik berupa rasa nyeri pada dada sebelah kiri dan menghilang ketika istirahat.

2. Trombosis

Trombosis adalah pembentukan bekuan pada lapisan dalam (endotel) pembuluh darah. Trombosis dapat menurunkan aliran darah atau secara total menyumbat pembuluh darah. Trombsis juga dapat terjadi pada lapisan endotel jantung. Trombosis pada arteri dapat menghentikan aliran darah ke area yang dialiri oleh pembuluh tersebut dan menyebabkan iskemik atau infark pada area tersebut.

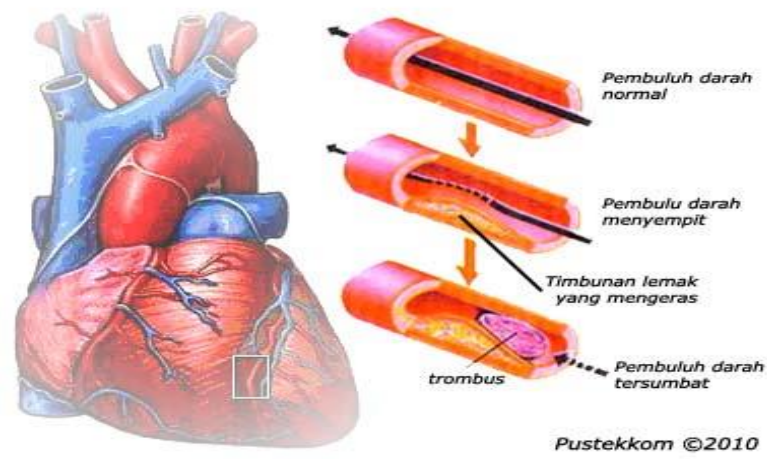

Gb. 6: Trombosis 


\section{Emboli}

Emboli adalah kumpulan bekuan darah (thrombus) atau bisa juga dari substansi lain seperti kolesterol yang terlepas dari pembuluh darah utama dan memasuki aliran darah yang dapat menuju kemana saja dan menyebabkan berbagai masalah termasuk stroke, jantung koroner, gagal ginjal ataupun emboli paru.

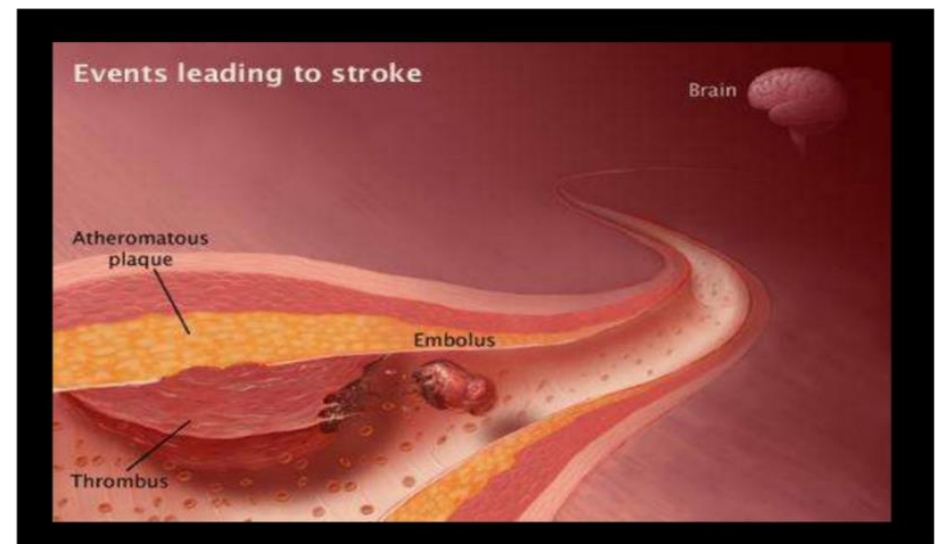

Gb.7: Emboli yang berasal dari trombus

4. Nekrosis

Nekrosis adalah keadaan terjadinya perubahan biokimia dan morfologik (tampilan) sel akibat cidera yang fata pada sel sehingga tidak dapat pulih kembali (ireversibel). Nekrosis juga disebut kematian sel (celluler death) yang dapat terjadi pada seluruh tubuh (somatic death) atau terbatas mengenai suatu jaringan hanya pada sel tertentu saja. 


\section{LATIHAN}

Tugas Mandiri:

1. Jelaskan penyebab jejas se?

2. Sebutkan 4 bentuk adaptasi sel?

3. Sebutkan 2 contoh agen fisik penyebab jejas sel?

\section{RANGKUMAN}

1. Sel adalah unit structural dan fungsional terkecil dari tubuh manusia, kerusakan pada sel dapat dapat berlanjut menjadi kerusakan jaringan.

2. Berbagai cidera setiap saat akan dialami oleh sel dengan berbagai penyebab seperti hipoksia, agen fisik, kimia, agen mikrobiologi dan mekanisme imun. Oleh karena itu sel harus melakukan mekanisme adaptasi dalam berbagai bentuk seperti atropi, hyperplasia, hipertropi dan metaplasia.

\section{TES FORMATIF}

1. Seorang laki-laki, umur 45 tahun masuk IGD akibat tersetrum saat melakukan perbaikan kabel korsleting sehingga menimbulkan luka dan cidera pada daerah lengan. Penyebab cidera adalah...
a. Agen Fisik
b. Bahan Kimia
c. Mikrobiologi
d. hipoksia
e. Keracunan

2. Seorang wanita, 60 tahun dirawat di Ruang ICCU akibat penyumbatan pada pembuluh darah koroner jantung. Diketahui ibu ini telah lama menderita hipertensi sejak 10 tahun yang lalu. Setelah dilakukan pemeriksaan echocardiography didapatkan perbesaran pada jantung (Kardiomegali). Pada pembesaran pada jantung terjadi proses adaptasi patologik sel dinamakan...

a. Hipertrofi 

b. Atrofi
c. Hiperplasia
d. Metaplasia
e. Nekrosis Sel

3. Seorang laki-laki, 60 tahun sudah setahun dirawat di rumah karena terkena stroke sehingga menyebabkan kelumpuhan pada bagian eksterimtas kanan bawah. Karena tidak pernah digerakkan sehingga otot kaki mengecil. Pada pengecilan otot kaki terjadi peruses adaptasi patologik sel dinamakan...
a. Hipertrofi
b. Atrofi
c. Hiperplasia
d. Metaplasia
e. Nekrosis Sel

4. Seorang laki-laki, berumur 45 tahun dirawat di ruang penyakit dalam karena menderita diabetes mellitus dan gangren. Saat melakukan luka gangrene ditemukan jaringan yang mati berwarna hitam dan harus segera diangkat agar tidak menyebar. Jaringan mati berwarna hitam pada luka gangrene disebut...
a. Nekrosis
b. Iskemik
c. Trombosis
d. Emboli
e. Atropi

5. Seorang perempuan, berumur 40 tahun masuk IGD dengan gejala stroke. Setelah dilakukan pemeriksaan CT-Scan didpatkan adanya sumbatan pada pembuluh darah di otak. Penyumbatan pembuluh darah otak bisa saja didapatkan dari serpihan dari substansi lemak yang disebut...
a. Nekrosis
b. Iskemik
c. Trombosis
d. Emboli
e. Atropi 


\section{GLOSARIUM}

DNA : Deoxyribo nucleotida acid

RNA : Ribonucleic acid

\section{DAFTAR PUSTAKA}

1. Kumar V, Cotran R.S, Robbins S.L. 2007. Buku Ajar Patologi Robbins Edisi . Jakarta. EGC

2. Nair, Muralitharan. Peate, Ian. 2015. Dasar-Dasar Patofisiologi Terapan. Jakarta. EGC

3. Price, Sylvia A. Wilson, Lorraine M. Patofisiologi Konsep Klinis Proses-Proses Penyakit Volume 2 Edisi 6. Jakarta: EGC

4. Tambayong, Jan. 2016. Patofisiologi Untuk Keperawatan. Jakarta: EGC 